\title{
KAJIAN TEORITIS TENTANG PERILAKU LESBIAN, GAY, BISEKSUAL, TRANSGENDER (LGBT) DALAM PERSPEKTIF PSIKOLOGIS DAN TEOLOGIS
}

\author{
Abd. Mukhid \\ Intitut Agama Islam Negeri ( IAIN) Madura
}

\begin{abstract}
There are two problems that want to be answered in this research, namely: (1) how is LGBT behavior in a psychological perspective? And (2) how is LGBT behavior in a theological perspective? This study uses a descriptive qualitative approach. Data collection techniques using interview, observation and documentation techniques. The location of the study was carried out in Lesp Backup, Mojokerto Regency with three informants using a purposive sampling technique. The results of the study show that in a psychological and theological perspective: (1) LGBT behavior is not taken from birth, but this behavior can be formed from childhood, such as since school in elementary or middle school or high school; (2) LGBT behavior is a form of deviant sexual behavior; (3) LGBT behavior becomes a lifestyle for the LGBT community; (4) LGBT actors in the social community are able to adjust well; (5) LGBT behavior deviates from the customs and culture of the community; (6) Factors that cause LGBT behavior can be caused by fostering parents in children from childhood; and (7) LGBT behavior can be cured, provided that there is strong intention.
\end{abstract}

Keywords: Perilaku LGBT, Konsep, Psikologis, Teologis 


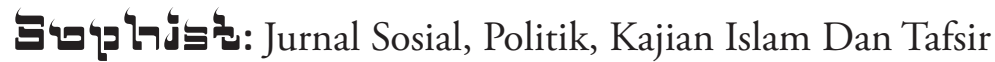

\section{A. Pendahuluan}

Akhir-akhir ini masyarakat Indonesia diributkan oleh isu yang sangat kontroversial terkait keberadaan lesbian, gay, biseksual, dan transgender (LGBT). Masyarakat yang awalnya tidak mengenal LGBT akhirnya mengenal apa itu LGBT. Komunitas LGBT ini keberadaannya semakin meresahkan masyarakat. Kekhawatiran masyarakat bukanlah tanpa alasan, sebab perilaku komunitas LGBT dianggap telah melanggar norma-norma agama dan merusak tatanan sosial. Selain itu, sasaran mereka adalah para pelajar, remaja, dan mahasiswa yang secara psikologis masih mengalami krisis jati diri, dan jiwanya labil. Pada usia ini, mereka masih membutuhkan sosok panutan yang dianggap cocok baginya. Celakanya, kebanyakan dari mereka belum memiliki pemahaman agama yang mendalam, maka dengan demikian, mereka menjadi sasaran empuk bagi komunitas LGBT. Sedang sikap masyarakat sendiri terhadap LGBT ada yang pro dan ada yang kontra. Pihak yang pro mengajukan argumen bahwa keberadaan LGBT telah mendapatkan legitimimasi sebagaimana nomenklatur Hak Azasi Manusia (HAM) yang mewajibkan setiap negara menjamin hak-hak dasar warganya.

Menurut deklarasi Perserikatan Bangsa-Bangsa (PBB), dan didukung oleh badan kesehatan dunia World Health Organization (WHO), hak dasar individu terdiri dari: hak hidup, hak kebebasan, dan hak memiliki kebahagiaan. ${ }^{1}$ Sedang pihak yang kontra memandang bahwa komunitas LGBT sebagai perusak agama dan penyebab turunnya azab Tuhan. ${ }^{2}$ Keberadaan komunitas LGBT dianggap telah menodai agama dan Undang-Undang RI No. 1 Thaun 1974 tentang Perkawinan, dimana "perkawinan adalah ikatan lahir batin

1 Dede Oetomo, Memperjuangkan Hak Asasi Manusia (HAM)Berdasarkan Identitas Gender dan Seksualitas Di Indonesia. Makalah dipresentasikan pada semiloka hak atas kebebasan pribadi bagi kelompok Lesbian, Gay, Biseksual, Interseksual, Transgender dan Transeksual. Komisi Nasional Hak Asasi Manusia, Kuta,15-16 Agustus 2006.

2 Farid Muttaqin, Observing the Islamic Theological Context: Contemporary Indonesian Muslim Feminist Agendas Toward Recognition of Gay and Lesbian Rights(Ohio University, Athen), hlm. 2.

Kajian Teoritis Tentang Perilaku Lesbian, Gay, Biseksual,.... 
antara seorang laki-laki dengan seorang perempuan sebagai suami istri dengan tujuan membentuk keluarga (rumah tangga) yang bahagia dan kekal berdasarkan Ketuhanan Yang Maha Esa”. ${ }^{3}$

Dalam Al-Qur'an surat an-Nahl ayat 72 Allah berfirman:

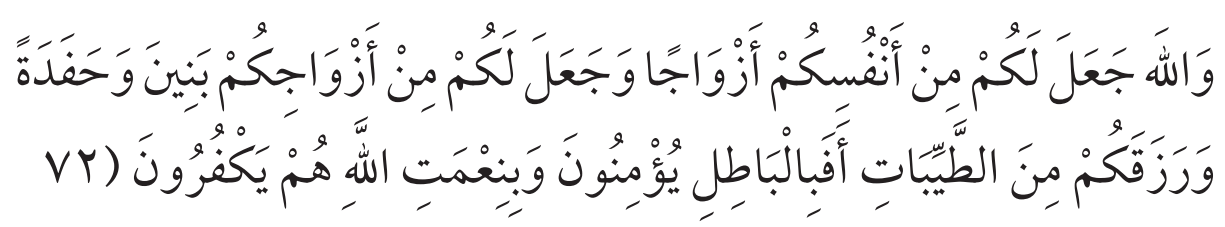

Artinya: Allah menjadikan bagi kamu isteri-isteri dari jenis kamu sendiri dan menjadikan bagimu dari isteri-isteri kamu itu, anak-anak dan cucucucu, dan memberimu rezeki dari yang baik-baik. Maka mengapakah mereka beriman kepada yang bathil dan mengingkari nikmat Allah? ${ }^{24}$

Adapun jika terjadi sebaliknya, yakni laki-laki suka sama lakilaki maka disebut dengan homoseksual, dalam al-Quran surat al-A'raf ayat 80-81 Allah Swt berfirman:

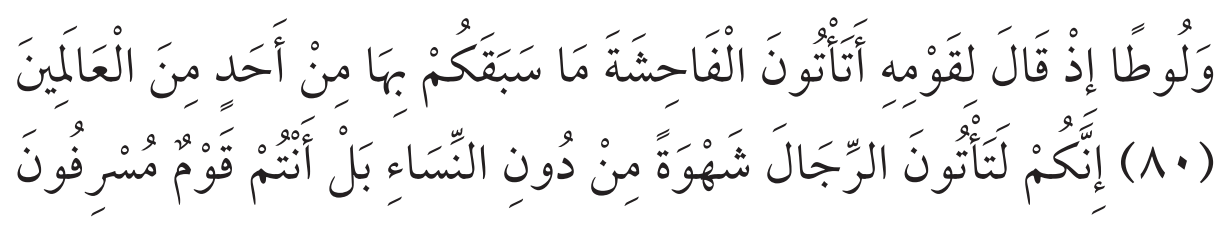

Artinya: Dan (Kami juga telah mengutus) Luth (kepada kaumnya). (Ingatlah) tatkala dia berkata kepada mereka: "Mengapa kamu mengerjakan perbuatan fahisyah itu, yang belum pernah dikerjakan oleh seorang pun (di dunia ini) sebelummu? Sesungguhnya kamu mendatangi lelaki untuk melepaskan nafsumu (kepada mereka), bukan kepada wanita, malah kamu ini adalah kaum yang melampaui batas. ${ }^{5}$

Rangkutimenyatakan bahwa(perbuatan fahisyah) penyimpangan seksual itu bukan hanya dilakukan oleh orang-orang atheis saja,

3 UU RI No. 1 Tahun 1974, 2007. Tentang Perkawinan dan Kompilasi Hukum Islam. (Bandung: Citra Umbara), hlm. 2.

4 Departemen Agama RI, 1989. Al-Qur'an dan Terjemahannya, (Semarang: CV TOHA PUTRA), hlm. 404.

5 Ibid., hlm. 228. 
melainkan juga dilakukan orang beragama, yang dilakukan karena api syahwat serta naluri-naluri hewaniah. ${ }^{6}$ Akibat perbuatan fahisyah ini, Fathi Yakan mengemukakan kekhawatiran George Harvard dalam bukunya Revolusi Seks, akan danya serangan bom seks yang setiap saat dapat meledak dan menghancurkan moral manusia serta mengancam kelangsungan hidup manusia itu sendiri. ${ }^{7}$

Salah satu dampak negatif akibat perilaku homoseksual adalah terjangkitnya penyakit AIDS (Acquired Immuno Deficiency Syndrome). AIDS adalah suatu kumpulan gejala yang disebabkan oleh infeksi HIV (Human Immunodeficiency Virus) yang menyebabkan hilangnya kekebalan tubuh sehingga penderita mudah terjangkit penyakit infeksi, yang secara perlahan dapat menyebabkan kematian. Berdasarkan data 2013, penderita AIDS di Indonesia terus mengalami kenaikan, dimana tercatat 3,1 juta pria merupakan penikmat seks bebas dan pelaku zina, 800 ribu lainnya berhubungan seksual sesama jenis. ${ }^{8}$

Selanjutnya Fathi Yakan menjelaskan pendapat James Ruston yang ditulis di harian New York Times yang dikutip Rangkuti bahwa bahaya tenaga seks lebih besar daripada bahaya tenaga nuklir. Hal ini dapat dibuktikan dari catatan resmi Dewan Kesehatan Dunia, bahwa terdapat puluhan juta orang melakukan homoseks, tiga juta orang di antaranya di Amerika. ${ }^{9}$ Terhadap hal ini, masyarakat mengutuk menganggap perilaku LGBT sebagai kelainan jiwa, kehinaan, abnormal dan perbuatan seks menyimpang yang dapat merusak tatanan sosial masyarakat, kehancuran akhlak, melawan takdir dan menjadi biang terjadinya azab Tuhan. ${ }^{10}$

6 Ramlan Yusuf Rangkuti, 2012. Homoseksual Dalam Perspektif Al-Qur'an, AsySyir'ah, Jurnal Ilmu Syariah dan Hukum, Vol. 46, No. 1, hlm. 291.

7 Fathi Yakan, 1989. al-Islam wa al-Jins, terjemahan Syafril Halim, Islam dan Seks (Jakarta: Al-Hidayah), hlm. 78.

8 Angka Penderita AIDS di Indonesia Terus Merangkak naik. Diakses tanggal 7 April 2016 dari : https://indocropcircles.wordpress.com/2013/12/01/angka-penderitaaids-di-indonesia-terus-naik/

9 Ramlan Yusuf Rangkuti, 2012. Homoseksual Dalam Perspektif Hukum Islam ..., hlm. 292.

10 Fathi Yakan. 1989. Al-Islam wa al-Jins. Terj. Syafril Jamil, Islam dan Seks.

Kajian Teoritis Tentang Perilaku Lesbian, Gay, Biseksual,.... 
Berdasarkan survey Kemenkes di 13 kota di Indonesia yang dilakukan sejak 2009-2013, tercatat pria yang bercinta dengan sesama jenis meningkat drastis, bahwa "pada 2009 laki-laki yang berhubungan seks dengan laki-laki meningkat dari 7\% menjadi 12,8\% pada 2013 atau meningkat 83 persen. ${ }^{11}$

Salah satu kabupaten di provinsi Jawa Timur dimana komunitas LGBT telah banyak pengikutnya adalah kabupaten Mojokerto. Fenomena perilaku LGBT ini sedang ngetren di kalangan pelajar dan generasi muda di Mojokerto, dan aktivitas mereka di tahap memprihatinkan. Berdasarkan berita yang bersumber dari media online yang dilaporkan oleh Misti pada tanggal 26 Pebruari 2016 bahwa Kepala Badan Pemberdayaan dan Keluarga Berencana (BKKB) Kabupaten Mojokerto Yudha Hadi mengatakan bahwa di Kabupaten Mojokerto sedikitnya terdapat 200 orang yang menjadi anggota LGBT. ${ }^{12}$ Mereka mulai berani menunjukkan aktivitasnya di tempattempat umum. Keberadaan dan jumlah komunitas LGBT tersebut telah meresahkan berbagai kalangan masyarakat di Mojokerto. Berdasarkan permasalahan tersebut peneliti tertarik untuk meneliti "Kajian Teorits Tentang Perilaku Lesbian, Gay, Biseksual, Transgender (LGBT) dalam Perspektif Psikologis dan Teologis"

\section{B. Pembahasan}

\section{Perilaku LGBT Perspektif Psikologis}

LGBT adalah singkatan dari Lesbian, Gay, Biseksual, dan Transgender. Lesbian adalah homoseksual antara sesama wanita, sedang gay adalah homoseksual antara sesama lelaki. ${ }^{13}$ Dalam

(Jakarta: Al-Hidayah), hlm. 10-14

11 Tommy Dwi Pranata. 2015. Perilaku dan realitas Sosial Kehidupan gay di Samarinda. eJournal Sosiatri-Sosiologi, Vol. 3, No.3, hlm. 135-150.

12 Misti P. Pemkab Mojokerto Sosialisasi Bahaya LGBT. Diakses tanggal 19 Maret 2016 dari: http://beritajatim.com/politik_pemerintahan/260469/pemkab mojokerto sosialisasi bahaya lgbt.html\#.VvdboUDkjIU

13 S. K. Putri, 2008. Proses Coming Out Pada Gay. Diunduh tanggal 28 Maret 2016 dari: http://www.gunadarma.ac.id/library/articles/graduate/psycholog y/2007/ 
bahasa Arab, homoseks disebut dengan liwath. Adapun biseksual adalah ketertarikan romantis, ketertarikan seksual, atau kebiasaan seksual kepada pria maupun wanita sekaligus. ${ }^{14}$ Sedang transgender adalah munculnya perasaan laki-laki atau perempuan pada fisik yang berbeda, baik dari female to male atau male to female yang membuat dirinya ingin hidup dalam identitas gender yang tidak sesuai dengan jenis kelaminya. ${ }^{15}$

Dari penjelasan di atas dapat diambil pengertian bahwa homoseksual dapat diartikan dengan kecenderungan yang kuat akan daya tarik erotis seseorang justru terhadap sesama jenis (wanita tertarik dengan wanita (lesbian) dan laki-laki tertarik dengan laki-laki (gay), tetapi identitas gender mereka (perasaan menjadi pria atau wanita) konsisten dengan anatomi seks mereka. ${ }^{16}$

a. Faktor-faktor Penyebab Terjadinya Perilaku LGBT

Kebanyakan para psikolog menyatakan bahwa lesbian, gay, biseksual dan trangender (LGBT) merupakan bentuk penyimpangan seksual, seks yang tidak normal. Beberapa pendapat menjelaskan penyebab perilaku LGBT karena berbagai faktor yang berbeda, yaitu: (1) faktor keluarga (pengalaman atau trauma di masa anak-anak seperti, seperti kekerasan yang dialami anak dari segi fisik, mental dan seksual yang membuat seorang wanita bersikap benci terhadap semua pria) ${ }^{17}$; (2) faktor pergaulan dan lingkungan (kebiasaan pergaulan dan lingkungan anak seperti ketika berada di asrama sekolah yang terpisah antaralaki-lakidanperempuandapatmengundang terjadinyahubungan

Artikel_10502236.pdf

14 American Psychological Association. 2013. Sexual Orientation, Homosexuality and Bisexuality. Diarsipkan dari versi aslinya 8 Agustus 2013. Diakses tanggal 21 Maret 2016 dari: https://leachpsychology.com/up loads/material_personal_sex_ orient.pdf.

15 K. A. Stieqlitz, 2010. Development, Risk, and Resilience of Transgender Youth. Journal of the Association of Nurses in AIDS Care, 21(3), hlm. 192-206.

16 Jeffrey S. Nevid, dkk., 2003. Psikologi Abnormal, (Jakarta: Erlangga), Edisi Kelima, Jilid 2, hlm. 75.

17 Abu Ameenah Philips dan Zafar Khan, 2003. Islam dan Homoseksual (Jakarta: Pustaka Zahra), Cet.1, hlm. 85

Kajian Teoritis Tentang Perilaku Lesbian, Gay, Biseksual,.... 
gay dan lesbian) ${ }^{18}$; (3) faktor biologis (penyimpangan seksual karena faktor genetika yang banyak dipengaruhi oleh hormon testeron, dapat mempengaruhi perilaku laki-laki mirip kepada perempuan $)^{19}$; dan (4) faktor moral dan akhlak (golongan homoseksual ini terjadi karena adanya pergeseran norma-norma susila yang dianut oleh masyarakat, serta semakin menipisnya kontrol sosial yang ada dalam masyarakat tersebut yang disebabkan karena lemahnya iman dan pengendalian hawa nafsu serta karena banyaknya rangsangan seksual ${ }^{20}$.

Menurut Walgito perilaku adalah suatu aktivitas yang mengalami perubahan dalam diri individu. Perubahan itu didapat dalam segi kognitif, afektif, dan dalam segi psikomotor. ${ }^{21}$ Perilaku seseorang dikelompokkan ke dalam perilaku wajar, perilaku dapat diterima, perilaku aneh, dan perilaku menyimpang. ${ }^{22}$ Dalam agama, perilaku yang baik adalah perilaku yang sesuai dengan tujuan penciptaan manusia ke dunia, yaitu untuk menghambakan diri kepada Tuhannya.

Watson, dalam Walgito, mengemukakan tiga karakteristik perilaku manusia yaitu: 1) Perilaku kasatmata, tetapi penyebab terjadinya perilaku secara langsung mungkin tidak dapat diamati; 2) Perilaku mengenal berbagai tingkatan, yaitu perilaku sederhana dan stereotip, seperti perilaku binatang bersel satu; perilaku kompleks, seperti sosial manusia; perilaku sederhana, seperti reflex, tetapi ada juga yang melibatkan proses mental biologis yang tinggi: 3) Perilaku bervariasi dengan klasifikasi: kognitif, afektif, dan psikomotorik, yang menunjuk pada sifat rasional, emosional dan gerakan fisik dalam

18 Masyitah Ibrahim, "Program Ikut Telunjuk Nafsu”. Diakses 17 Maret 2016, dari : http://www.utusan.com.my

19 Sri Habsari, Bimbingan dan Konseling SMA. Diakses pada 17 Maret 2016 dari : http://books.google.co.id

20 Syed Hassan, May 2011. Kenapa Berlakunya Kecelaruan Jantina, (Jurnal alIslâm) hlm. 35

21 Bimo Walgito. 2005. Bimbingan dan Konseling (Studi dan Karir), (Yogyakarta: Andi), hlm. 168

22 Albarracín, Dolores, Blair T. Johnson, \& Mark P. Zanna. 2005. The Handbook of Attitude. (Routledge), hlm. 74-78 


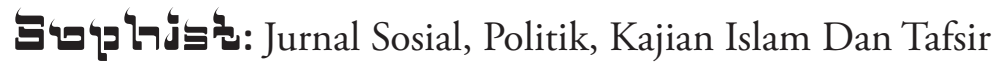

berperilaku. ${ }^{23}$

Notoatmodjo dalam Walgito, mengelompokkan perilaku manusia menjadi dua bagian berdasarkan teori "S-O-R" Skinner yaitu: (1) perilaku tertutup (covert behavior), perilaku ini terjadi bila respon terhadap stimulus tersebut masih belum dapat diamati orang lain (dari luar) secara jelas; (2) perilaku terbuka (overt behavior), perilaku ini terjadi bila respon terhadap stimulus sudah berupa tindakan/praktik, ini dapat diamati orang lain dari luar. ${ }^{24}$

b. Pengertian Psikologi

Ditinjau dari asal katanya, psikologi berasal dari bahasa Yunani Kuno yaitu "psyche" yang berarti "jiwa (ruh)" dan "logos" yang berarti "ilmu”. Jadi psikologi adalah ilmu pengetahuan tentang jiwa atau ilmu jiwa. Adapun secara istilah para ahli mendefinisikan psikologi sesuai dengan sudut pandang masing-masing sehingga muncul berbagai aliran dalam psikologi, ${ }^{26}$ diantaranya adalah sebagai berikut:

a. Wilhelm Wundt

Menurut Wilhelm Wundt psikologi itu merupakan ilmu pengetahuan tentang kesadaran manusia. Wundt percaya bahwa gejalagejala jiwa tersusun dari beberapa elemen. Sehingga dalam menganalisa elemen-elemen kejiwaan para ahli psikolog mempelajari melalaui proses elementer dari kesadaran manusia. Dari sisnilah dapat diketahui bahwa obyek utama dalam psikologi menurut Wilhelm Wundt adalah kesadaran. ${ }^{27}$

b. Clifford T. Margan

Menurut Clifford T. Margan, psikologi adalah ilmu yang mempelajari tentang tingkah laku manusia dan hewan. Jadi para

23 Bimo Walgito. 2004. Pengantar Psikologi Umum. (Jakarta: Andi), hlm. 19.

24 Ibid., hal. 21.

25 Bimo Walgito, Pengantar Psikologi Umum (Yogyakarta: Andi Offset, 2002), hlm. 1 hlm. 9 .

26 Sarlito Wirawan Sarwono, Pengantar Psikologi (Jakarta: Bulan Bintang, 1982),

27 Bimo Walgito, Pengantar Psikologi Umum, hlm. 7

60 Kajian Teoritis Tentang Perilaku Lesbian, Gay, Biseksual,.... 
psikolog secara sistematis akan mengamati tingkah laku baik binatang maupun manusia. Ia juga mengatakan bahwa sebenarnya antara tingkah laku manusia dan tingkah laku hewan itu banyak kesamaannya. Oleh karena itu studi tentang tingkah laku binatang dapat memberi bantuan besar kepada para psikolog didalam memahami tingkah laku manusia. ${ }^{28}$

\section{c. Perilaku LGBT Perspektif Para Ahli Psikologi}

Keberadaan LGBT masih mengundang pro dan kontra di kalangan masyarakat. Alasannya jelas, perilaku mereka bertentangan dengan nilai agama dan budaya di Indonesia. Oleh karena itu, penting untuk dikemukakan pandangan para psikolog tentang keberadaan kaum LGBT.

Psikolog Klinis dan Hipnoterapi, Liza Marielly Djaprie, lulusan Magister Psikologi Dewasa Universitas Indonesia menjelaskan, dalam ilmu psikologi dan kamus besar kejiwaan, LGBT tidak masuk dalam gangguan jiwa yang dialami seseorang. Kondisi yang mereka alami dianggap keunikan pada diri orang tersebut, sama halnya seperti kepribadian introvert atau ekstrovert, masuk ke dalam karakter bukan bentuk penyakit. ${ }^{29}$

Selanjutnya dia menyatakan bahwa terbentuknya mereka menjadi LGBT bisa karena pengaruh lingkungan, bawaan lahir, atau memang karena trauma akibat pengalaman tertentu. Jika mereka ingin 'normal' maka itu semua bisa diperbaiki. Ada orang yang memang terlahir memiliki bawaan lesbian atau homoseksual, namun karena lingkungan mereka tidak ada yang demikian, maka mereka menjadi heteroseksual. Tapi ada pula yang sebaliknya, terlahir sebagai heteroseksual, namun berada di lingkungan homoseksual, jadi mereka mencari pasangan sesama jenis. hlm. 10 .

28 Clifford T. Margan, Psikologi Sebuah Pengantar (Jakarta: Prasya Paramita, 1986),

29 Liza Marielly Djaprie, Pandangan Psikolog tentang LGBT, dalam Okezone Lifestyle, diperoleh dari http://lifestyle.okezone.com/read/2016/01/26/196/1297603/ pandangan-psikolog-tentang-lgbt, diakses 16 Agustus 2016. 
Selanjutnya menurut tokoh psikologi klinis, Freud, dia melihat gay terjadi karena pola asuh dan traumatis terhadap kekerasan dari sang ayah. Psikologi klinis pada awalnya melihat homoseksualitas sebagai patologi abnormal, mental illness dan dosa. Para pengikut Freud yang melihat deviasi seksual ini sebagai patologis dan sakit. Pada tahun 1910, Freud memandang homoseksualitas sebagai abnormal karena heterosexuality was the guiding telos of development and ultimately the only correct decision. ${ }^{30}$ Selanjutnya dijelaskan bahwa sejak tahun 1899, penelitian mengenai orientasi seksual non-heteroseksual telah diadakan. Peneliti Magnus Hirscheld, Michael Bailey, Richard Pillard, dan Dean Hamer menyatakan bahwa homoseksualitas adalah bawaan genetik. Salah satu buktinya adalah keberadaan kromosom $\mathrm{Xq}-28$, yaitu gen yang terdapat pada orang-orang yang mengalami kecenderungan homoseks. Tetapi pada tahun 1998, Profesor George Rice menyatakan bahwa teori itu tidak benar. Pada tahun yang sama, Prof. Alan Sanders mengadakan sebuah riset kepada 54 pasang kakak beradik, yang salah satunya homoseksual, dan hasilnya adalah, meskipun kakak beradik itu sama-sama memiliki kromosom Xq-28, tidak semua mereka memiliki kecenderungan orientasi seksual yang sama. Selanjutnya tahun 2014 para peneliti mengumpulkan 400 responden gay, dan hasilnya, memang kaum gay kebanyakan memiliki keunikan kromosom ini. Tetapi jika kita cermati, ada perbedaan mencolok antara penelitian Profesor Rice dan Sanders dengan para peneliti modern di tahun 2014.

Rice dan Sanders, secara adil memeriksa pasangan kakak beradik yang memiliki kesamaan gen, dan apakah semua orang yang memiliki kromosom Xq-28 sudah pasti gay. Sedangkan riset tahun 2014 memeriksa semua orang gay dan memastikan apakah mereka semua memiliki kromosom Xq-28. Di sini terlihat bahwa kromosom Xq-28 terdapat pada mayoritas homoseksual, tetapi ini tidak lantas

30 Khanis Suvianita. Pandangan Psikolog Tentang kaum LGBT, diperoleh dari http:// www.suarakita.org/2015/10/kisah-khanis-suvianita-pandangan-psikolog-tentangkaum-lgbt/, diakses 13 Agustus 2016. 
membuktikan bahwa semua orang yang memiliki kromosom tersebut lantas menjadi seorang homoseks. Ada kemungkinan bagi orang-orang, yang walaupun memiliki kromosom itu, tetap menjadi seorang heteroseksual. Ini membuktikan bahwa bawaan genetik hanya mempengaruhi mungkin 5\% dari orientasi seksual seseorang. Sedangkan 95\% lainnya ditentukan oleh banyak faktor yang lain.

Sebuah penelitian dilakukan oleh Constance R. Sullivan Blum ("The Natural Order of Creation": Naturalizing Discourses in the Christian Same-Sex Marriage Debate, 2006) dengan pendekatan social terhadap LGBT teis (non-atheis) mengenai apakah mereka berpikir bahwa orientasi seksual mereka adalah bawaan genetik atau pilihan mereka sendiri. Beberapa responden yakin bahwa orientasi seksual mereka sebagai LGBT merupakan born this way, alias merupakan bawaan genetik. Tetapi ada pula beberapa responden yang mengakui bahwa mereka tidak dilahirkan dalam keadaan seperti itu. Mereka mengakui bahwa mereka pernah menjalani orientasi seksual sebagai heteroseksual sebelum mereka menjadi seorang homoseksual atau biseksual. Berbagai penelitian ini membuktikan bahwa orientasi seksual seseorang tidak ditentukan semata-mata oleh faktor genetika. Ini terbukti bahwa sekalipun seseorang terlahir dengan kromosom Xq28, ia masih dapat menjadi seorang heteroseksual. Orientasi seksual seseorang lebih ditentukan oleh faktor psikologis dan lingkungan/ pergaulan. ${ }^{31}$

Dalam tulisan Bigman Sirait tentang LGBT Dalam Perspektif Medis dan Psikologis dijelaskan bahwa Dr. Robert Spitzer seorang psikiatris dari Columbia University adalah tokoh penting yang berjuang menghilangkannya dari daftar kelainan. Namun pada tahun 2003 dia mempublikasikan penelitiannya terhadap 200 homo, yang ternyata menunjukkan keberhasilan perubahan orientasi seksual setelah menjalani terapi. Artinya seorang homoseks bisa menjalani

31 Jessica Layantala. LGBT: Genetik, Psikologi, Sosial, Atau?, dalam Kompasiana. com, diperoleh dari http://www.kompasiana.com/jessicalayantara/lgbt-genetikpsikologi-sosial-atau_56bbed9b927a610105630128, diakses 15 Agustus 2016. 
terapi untuk menjadi normal. Dengan segera dia mendapat tekanan dari komunitas gay, dan akhirnya Spitzer mencabut kembali hasil penelitian yang dipublishnya. Spitzer dikritik atas sikap tidak profesionalnya itu oleh psikolog seperti; Jerry A, Elton L,Moose Anne, dll. ${ }^{32}$ Selanjutnya Sirait menjelaskan bahwa Neil N. Whitehead seorang ahli biokimia yang bebas dari pengaruh kaum homoseks, pada tahun 2000 mengatakan bahwa berdasarkan survey modern dari lembaga independen yang profesional dan tidak memihak, menunjukkan bahwa kaum LGBT hanya sekitar 2-3\%, bukan 10\%, sebagaimana yang dikemukakan Alferd C.Kensey. Hal ini berarti tidak sedikit para peneliti ternyata adalah seorang homo atau memiliki kecenderungan sehingga orientasi penelitian bisa jadi subjektif dan kehilangan sikap profesionalnya.

\section{Perilaku LGBT Perspektif Teologis}

a. Pengertian Teologi

Secara bahasa, kata "teologi" terdiri dari dua kata, yaitu "theos" yang berarti Tuhan dan "Logos" yang berarti Ilmu. ${ }^{33}$ Jadi teologi adalah ilmu tentang Tuhan atau ketuhanan. Secara terminologi, teologi adalah ilmu yang membahas tentang Tuhan dan segala sesuatu yang terkait dengannya, ${ }^{34}$ juga membahas hubungan Tuhan dengan manusia dan hubungan manusia dengan Tuhan. ${ }^{35}$

Teologi atau agama, menurut Atang Abd Hakim dan kawankawan, mengandung dua kelompok ajaran. Pertama, ajaran dasar yang diwahyukan Tuhan melalui Rasul-Rasul-Nya kepada masyarakat manusia. Kedua, penjelasan-penjelasan para pemuka atau pakar agama

32 Bigman Sirait, LGBT Dalam PerspektifMedis dan Psikologis, diperoleh dari http:// www.kompasiana.com/bigmansirait/lgbt-dalam-perspektif-medis-dan psikologis

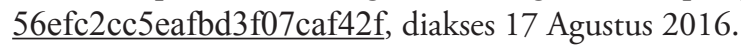

33 A. Hanafi, 1989. Pengantar Theology Islam. Cet. V. (Jakarta: Pustaka AlHusna), hlm. 11

34 Ya'kub Hamzah, 1991. Filsafat Agama Titik Temu Akal dengan Wahyu, (Jakarta: Pedoman Ilmu Jaya), hlm. 10.

35 Amsal Bachtiar, 1997. Filsafat Agama. Cet. Islam. ( Jakarta: Logos Wacana Ilmu), hlm. 18.

64 Kajian Teoritis Tentang Perilaku Lesbian, Gay, Biseksual,.... 
yang membentuk ajaran agama. Ajaran dasar agama bersifat absolut, mutlak benar, tidak berubah dan tidak bisa diubah, sedangkan penjelasan ahli agama bersifat relatif, nisbi berubah dan dapat diubah sesuai dengan perkembangan zaman. ${ }^{36}$ Dengan demikian, dalam teologi atau agama, masih terbuka kemungkinan adanya dialog atas hal-hal yang normatif. Dalam konteks Islam, teologi dapat dimaknai dengan ilmu yang secara sistematis membicarakan tentang persoalan ketuhanan dan alam semesta menurut perspektif Islam yang harus diimani, dan hal-hal lain yang terkait dengan ajaran Islam yang harus diamalkan, guna mendapatkan keselamatan hidup (dunia dan akhirat). ${ }^{37}$

\section{Cakupan Pembahasan Teologi}

Adapun materi-materi yang terkandung dalam Teologi, lebih luas cakupannya dibandingkan dengan Fiqih. Fiqih membahas soal halal dan haram, sedang teologi, selain membahas soal Ketuhanan, juga membahas masalah-masalah iman dan kafir. Namun, sebagaimana telah diketahui, bahwa Islam pada hakekatnya merupakan satu 'tata kehidupan' yang total dan menyeluruh, yang mencakup seluruh aspek kehidupan manusia secara komprehensif, yang di dalamnya, selain membahas masalah-masalah agama, juga mengatur masalahmasalah politik, pengadilan, perdagangan, dan lain sebagainya (seperti perkawinan), yang karenanya, praktis tidak ada aspek kehidupan manusia yang tidak tersentuh oleh hukum/aturan Islam. Sedang sumber hukum/aturan Islam yang pokok adalah Al-Qur-an dan Hadits.

Berkaitan dengan penelitian ini, maka pembahasan LGBT dalam perspektif teologis akan dilihat dari halal haramnya atau terpuji tercelanya perbuatan LGBT dilihat dari dalil-dalil nash dan pendapat

36 Atang Abd Hakim, dkk, 1999. Metodologi Studi Islam. Cet. I. (Bandung: Remaja Rosdakarya), hlm. 57.

37 Lembaga Theologi Surakarta (LTS), Pengertian Teologi Menurut Islam, diperoleh dari https://theologisurakarta.wordpress.com/2013/07/08/pengertian-teologi-menurutislam/, diakses 15 Oktober 2016. 


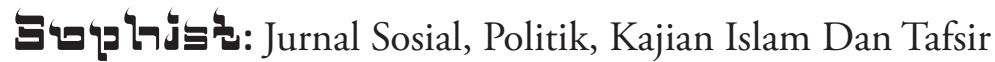

para ahli agama.

\section{Perdebatan masalah LGBT Perspektif Teologis}

Dalam beberapa dasawarsa ini kaum feminis dan komunitaskomunitas LGBT di Indonesia selalu mengaitkan hak-hak dasar komunitas LGBT sebagai warga negara dengan interpretasi dan justifikasi teologis. Mereka meninjau kembali penginterpretasian teks-teks keagamaan untuk melihat bagaimana proses justifikasi etis, kehinaan, keganjilan dan stigma-stigma negatif yang dilabelkan kepada mereka. Dalam hal ini, teks-teks keagamaan kerap kali dijadikan sebagai justifikasi tekstual untuk menghukumi mereka. ${ }^{38}$

Masalah teologis selama ini memang menjadi titik penting di dalam perdebatan LGBT dan homoseksualitas. Perlawanan masyarakat yang religius, khususnya Islam, adalah tantangan besar bagi legalisasi hak-hak seksual kaum LGBT. Colin Spencer mencatat bahwa negaranegara Islam atau yang mayoritas Muslim masih menjadi tempat yang tidak mengakomodasi hak seksual homoseks dan LGBT. Oleh karena itu, wajar apabila upaya pembongkaran terhadap ajaran agama yang dianggap heteronormatif giat dilakukan oleh akademisi muslim pendukung LGBT di negara mayoritas muslim seperti Indonesia. ${ }^{39}$

Di Indonesia, gerakan menuntut legalitas LGBT mendapatkan dukungan penting dari akademisi dan pegiat feminisme, ${ }^{40} \mathrm{G}:$ ISystem Volume Information|PEN lgbt - untuk jurnal Karsa 2017--draft| penyimpangan orientasi seksual (Kajian Psikologis dan Teologis) - This is Gender.htm - ftn3 misalnya publikasi ilmiah Jurnal Justisia edisi 25, Th. XI 2004 di Fakultas Syari'ah IAIN Wali Songo. ${ }^{41}$ Akademisi muslim liberal yang menulis di dalam jurnal tersebut secara tegas

38 Noviandy, LGBT Dalam Kontroversi Sejarah Seksualitas dan Relasi Kuasa (Sebuah Pengantar), diperoleh dari http://noviandy.com/wp-content/uploads/2014/08/lgbt-dalamkonteks.pdf, diakses tanggal 17 Agustus 2016.

39 Colin Spencer, 2011.Sejarah Homoseksualitas dari Zaman Kuno Hingga Sekarang, diterj oleh Ninik Rochani Sjams, (Bantul: Kreasi Wacana), cet ke-2, hlm.472.

40 Adian Husaini, 2012.Seputar Paham Kesetaraan Gender, (Depok: Adabi Press), hlm. 7.

41 Lihat Justisia, Indahnya Kawin Sesama Jenis, edisi 25, Th. XI 2004

Kajian Teoritis Tentang Perilaku Lesbian, Gay, Biseksual,.... 
mendukung semua jenis ekspresi seksual dan mengajak masyarakat setuju terhadap legalisasi perkawinan sejenis dan pengakuan untuk para penyimpang seksual lainnya.

3. Pandangan Islam Terhadap LGBT atau Homoseksual

Pandangan Islam terhadap homoseksualitas selain didasarkan atas penemuan ilmuwan, harus pula didasarkan atas wahyu al-Qur'an dan Hadis Nabi. Penilaian terhadap homoseksualitas tidak berubah seiring perkembangan masyarakat, melainkan tunduk pada keputusan Allah. Oleh karena itu, para ulama telah sepakat bahwa homoseksualitas adalah sesuatu yang terlarang, berdasarkan keterangan wahyu, ${ }^{42}$ dan bukan karena pengaruh heteronormativisme seperti yang diyakini pemikir liberal. ${ }^{43}$

Pemikir Musdah Mulia dan Husein Muhammad membedakan liwāt dengan homoseksual. Menurut mereka berdua, liwāt adalah perbuatan sodomi atau anal seks yang bisa dilakukan siapa saja termasuk pria heteroseks dan biseksual, sedangkan homoseksualitas lebih bersifat psikologis sehingga lebih tepat digunakan istilah mukhannas. ${ }^{44}$ Menurut Husen Muhammad dkk, arah argumen mereka berdua adalah untuk membenarkan homoseksualitas sebab para ahli fikih memang menerima adanya mukhannas bi al-khalq, yaitu mereka yang terlahir sebagai pria dengan sifat-sifat feminin. Inti dari pendapat ini adalah mengarahkan pengharaman hanya kepada tindakan sodomi (praktik anal seks) sedangkan orientasi homoseksual harus diterima dengan rida. ${ }^{45}$

Argumen dan pandangan mereka tersebut di atas tidak tepat, baik dari sudut pandang psikologi maupun Islam. Istilah mukhannas lebih tepat diartikan effeminate yang berarti "keperempuanperempuanan" atau "bersifat seperti perempuan". Hadis tentang 42 Qasim Nurseha, 2010. Kekeliruan Kaum Liberal Soal Homoseksual, ISLAMIA, 3.5., hlm. 141.

43 Husein Muhammad dkk., Fiqh Seksualitas Risalah Islam untuk Pemenuhan Hak-hak Seksualitas, (tt: PKBI, tth), hlm. 16-17.

44 Husein Muhammad dkk., Fiqh Seksualitas Risalah Islam ... ,hlm. 90.

45 Ibid., hlm. 91-95. 
mukhannas jelas merujuk kepada keadaan ini. Rasulullah bersabda yang diriwayatkan Ibnu Abbas di dalam Sahih Bukhari:

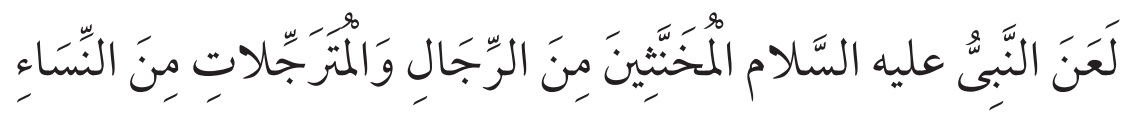

Artinya: "Rasulullah melaknat laki-laki yang menyerupai perempuan dan perempuan yang menyerupai laki-laki."

Menurut Ibnu Baththal, Rasulullah melaknat mereka bukan karena memang adanya sifat perempuan dalam dirinya yang merupakan ciptaan Allah. Laknat itu disebabkan oleh mereka yang memperturutkan kecenderunganitudan berdandansepertiperempuan, laknat ini juga berlaku bagi laki-laki tulen yang sengaja menyerupai perempuan. ${ }^{4646}$ Jadi istilah mukhannas tidak ada kaitannya dengan orientasi seksual terhadap sesama jenis, melainkan pada perilaku menyerupai penampilan lawan jenis, maka ia lebih tepat diartikan effeminate, bukan homosexual. Mengidentikkan homoseksualitas dengan effeminate jelas keliru. Mengasosiasikan kaum homoseksual dengan sifat tersebut, oleh psikolog dan pembela hak-hak LGBT justru dianggap homofobia. ${ }^{47}$

Istilah yang tepat untuk homoseksualitas adalah istilah liwạt (اللواط) sedangkan pelakunya disebut lütiy (اللوطي), para ulama dari kalangan ahli fikih, mufassir, ahli hadis dan ahli bahasa telah sepakat dengan penggunaan terminologi liwāt dan lụtiy. ${ }^{48}$ Istilah liwät dan lütiy bukan saja merujuk kepada tindakan seksual (sexual behavior) tapi juga merujuk kepada orientasi seksual, yang secara psikologis melibatkan perasaan cinta dan ketertarikan. Hal ini bisa dilihat dari akar kata " لوط" yang secara etimologis mengandung pengertian cinta dan melekat atau cinta yang melekat di hati (al-hub al-lazziq bi al-

46 Abu al-Hasan Ali bin Khalaf bin Abdil Malik bin Baththal al-Bakri al-Qurtubi, 2003. Syarhu Sahih al-Bukhari li Ibni al-Baththal, (Riyad: Maktabah al-Rusyd), vol IX, hlm. 141-142.

47 Brent L. Pickett, Historical Dictionary of Homosexuality,...hlm. 93.

48 Bakr bin Abdillah Abu Zayd, Mu'jam Manahi al-Lafdzhiyah wa Ma'ahu Fawaid fi Alfadz, (Riyad: Dar al-'Ashimah, 1996), hlm. 47 
qalbi) sebagaimana disebutkan di dalam Lisān al-Arab. ${ }^{49}$ Meskipun istilah liwāt sesungguhnya diambil dari nama Nabi Luth, tapi makna kebahasaan yang terkandung di dalam akar katanya tetap mengikut di dalam kata liwāt dalam kaitannya dengan homoseksualitas.

\section{Penutup}

Pandangan Islam terhadap homoseksualitas selain didasarkan atas penemuan ilmuwan, harus pula didasarkan atas wahyu al-Qur'an dan Hadis Nabi. Penilaian terhadap homoseksualitas tidak berubah seiring perkembangan masyarakat, melainkan tunduk pada keputusan Allah. Oleh karena itu, para ulama telah sepakat bahwa homoseksualitas adalah sesuatu yang terlarang, berdasarkan keterangan wahyu dan bukan karena pengaruh heteronormativisme seperti yang diyakini pemikir liberal.

Istilah yang tepat untuk homoseksualitas adalah istilah liwät (اللواط) sedangkan pelakunya disebut lütiy (اللوطي), para ulama dari kalangan ahli fikih, mufassir, ahli hadis dan ahli bahasa telah sepakat dengan penggunaan terminologi liwät dan lütiy Istilah liwāt dan lütiy bukan saja merujuk kepada tindakan seksual (sexual behavior) tapi juga merujuk kepada orientasi seksual, yang secara psikologis melibatkan perasaan cinta dan ketertarikan. Hal ini bisa dilihat dari akar kata "لوط" yang secara etimologis mengandung pengertian cinta dan melekat atau cinta yang melekat di hati (al-hub al-lazziq bi alqalbi) sebagaimana disebutkan di dalam Lisān al-Arab.

Meskipun istilah liwät sesungguhnya diambil dari nama Nabi Luth, tapi makna kebahasaan yang terkandung di dalam akar katanya tetap mengikut di dalam kata liwāt dalam kaitannya dengan homoseksualitas.

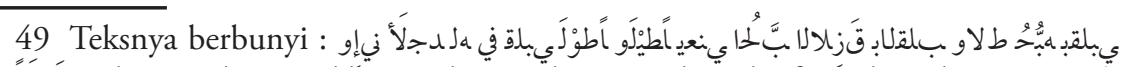

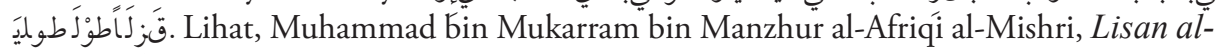
'Arab, (Beirut: Dar as-Shadir, tt) vol. VII. Hlm. 394.

Abd. Mukhid 


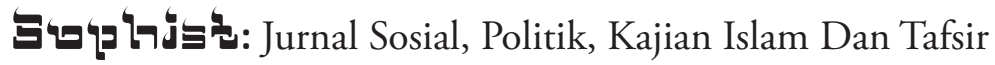

\section{Daftar Pustaka}

Abu Zayd, Bakr bin Abdillah. 1996. Mujjam Manahi al-Lafdzhiyah wa Máahu Fawaid fi Alfadz, (Riyad: Dar al-'Ashimah).

Albarracín, Dolores, Blair T. Johnson, \& Mark P. Zanna. 2005. The Handbook of Attitude. (Routledge).

Al-Mishri, Tt.,Muhammad bin Mukarram bin Manzhur al-Afriqi. Lisan al-Arab, (Beirut: Dar as-Shadir) vol. VII.

Al-Qurtubi, Abu al-Hasan Ali bin Khalaf bin Abdil Malik bin Baththal al-Bakri 2003. Syarhu Sabih al-Bukhari li Ibni alBaththal, (Riyad: Maktabah al-Rusyd), vol IX, hlm.

American Psychological Association. 2013. Sexual Orientation, Homosexuality and Bisexuality. Diarsipkan dari versi aslinya 8 Agustus 2013. Diakses tanggal 21 Maret 2016 dari: https://leachpsychology.com/up loads/material_ personal_sex_orient. pdf.

Arifin, Zainal. 2011. Penelitian Pendidikan Metode dan Paradigma Baru, (Bandung: Rosda Karya).

Ayub, (Peserta Program Kaderisasi Ulama (PKU) UNIDA Gontor dan YDSA Surabaya). Tt. Penyimpangan Orientasi Seksual: (Kajian Psikologis dan Teologis), diperoleh dari: http://thisisgender. com/penyimpangan-orientasi-seksual-kajian-psikologis-danteologis/, diakses tanggal 2 Juli 2016.

Bachtiar, Amsal. 1997. Filsafat Agama. Cet. Islam. ( Jakarta: Logos Wacana Ilmu).

Baharuddin, 2011. Aktualisasi Psikolog Islam, (Yogyakarta: Pustka Pelajar).

Buku Bapeda. Kab.Mojokerto 2013. Diperoleh dari: http://bappeda. jatimprov.go.id/bappeda/wp-content/uploads/potensi-kab-

70 Kajian Teoritis Tentang Perilaku Lesbian, Gay, Biseksual,.... 
kota-2013/kab-mojokerto-2013.pdf, diakses pada 15 Agustus 2016.

Bungin, Burhan. 2008. Metodologi Penelitian Kualitatif, (Jakarta : Raja Grafindo Persada).

Byrd, A. Dean dan Olsen, Stony. 2001. "Homosexuality: Innate and Immutable." Regent UL Rev. 14.

Chasanah, Nur. 2014. Studi Komparatif Hukum Positif dan Hukum

Islam di Indonesia Mengenai Perkawinan Sejenis. Jurnal Cendekia, Vol. 12, No. 3.

Departemen Agama RI, 1989. Al-Qur'an dan Terjemahannya, (Semarang: CV Toha Putra).

Divisi Litbang dan Pendidikan Komnas Perempuan, Tt., Dari Suara Lesbian, Gay, Bisexual, dan Transgender (LGBT) - Jalan Lain Memahami Hak Minoritas, diperoleh dari: https://www. scribd.com/doc/236500262/ Dari-

Djaprie, Liza Marielly. Pandangan Psikolog tentang LGBT, dalam Okezone Lifestyle, diperoleh dari: http://lifestyle.okezone. com/read/2016/01/26/ 196/1297603/pandangan-psikologtentang-lgbt, diakses 16 Agustus 2016.

Habsari, Sri. Bimbingan dan Konseling SMA. Diakses pada 17 Maret 2016 dari : http://books.google.co.id

Hakim, Atang Abd. dkk, 1999. Metodologi Studi Islam. Cet. I. (Bandung: Remaja Rosdakarya).

Hamzah, Ya'kub. 1991. Filsafat Agama Titik Temu Akal dengan Wahyu, (Jakarta: Pedoman Ilmu Jaya).

Hanafi, A. 1989. Pengantar Theology Islam. Cet. V. (Jakarta: Pustaka Al-Husna).

Hassan, Syed. May 2011. Kenapa Berlakunya Kecelaruan Jantina, 


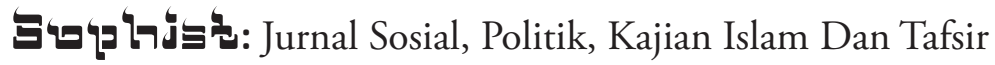

(Jurnal al-Islâm) hlm. 35

Hawari, Dadang. 2009. Pendekatan Psikoreligi pada Homoseksual, (Jakarta: Balai Penerbitan FKUI).

Husaini, Adian. 2012.Seputar Paham Kesetaraan Gender, (Depok: Adabi Press), hlm. 7.

Ibrahim, Masyitah. "Program Ikut Telunjuk Nafsu”. Diakses 17 Maret 2016, dari : http://www.utusan.com.my

Jeffrey S. Nevid, dkk., 2003. Psikologi Abnormal, (Jakarta: Erlangga), Edisi Kelima, Jilid 2.

Jessica Layantala. LGBT: Genetik, Psikologi, Sosial, Atau?, dalam Kompasiana.com, diperoleh dari: http://www.kompasiana. $\mathrm{com} / \quad$ jessicalayantara/lgbt-genetik-psikologi-sosialatau 56bbed9b927a6101056 30128, diakses 15 Agustus 2016.

Jurnal Justisia, Indahnya Kawin Sesama Jenis, edisi 25, Th. XI 2004.

Koran Sindo. Gay dan Lesbi Pelajar Marak. 18-02-2016.

Lembaga Theologi Surakarta (LTS), Pengertian Teologi Menurut Islam, diperoleh dari:https://theologisurakarta.wordpress. com/2013/07/08/pengertian-teologi-menurut-islam/, diakses 15 Oktober 2016.

Marak Pelajar Gay dan Lesbian, BKBPP dan MUI Kota Mojokerto Gencar Sosialisasi. Diperoleh dari: http://www.bangsaonline. com/berita/19592 Imarak-pelajar-gay-dan-lesbian-bkbppdan-mui-kota-mojokerto-gencar-sosialisasi, diakses 10 Agustus 2016.

Margan, Clifford T. 1986. Psikologi Sebuah Pengantar (Jakarta: Prasya Paramita).

Misti P. Pemkab Mojokerto Sosialisasi Bahaya LGBT. Diakses

72 Kajian Teoritis Tentang Perilaku Lesbian, Gay, Biseksual,.... 
tanggal 19 Maret 2016 dari: http://beritajatim.com/politik_ pemerintahan/260469/pemkab_mojokerto sosialisasi bahaya lgbt.html\#.VvdboUDkjIU

Muhammad, Husein. dkk., Tt., Figh Seksualitas Risalah Islam untuk Pemenuhan Hak-hak Seksualitas, (PKBI).

Muttaqin, Farid. Observing the Islamic Theological Context: Contemporary Indonesian Muslim Feminist Agendas Toward Recognition of Gay and Lesbian Rights(Ohio University, Athen).

Noviandy, LGBT Dalam Kontroversi Sejarah Seksualitas dan Relasi Kuasa (Sebuah Pengantar), diperoleh dari: http://noviandy. com/wp-content/uploads/2014/08/lgbt-dalam-konteks.pdf, diakses tanggal 17 Agustus 2016.

Nurseha, Qasim. 2010. Kekeliruan Kaum Liberal Soal Homoseksual, ISLAMIA, 3.5.

Oetomo, Dede. Memperjuangkan Hak Asasi Manusia (HAM) Berdasarkan Identitas Gender dan Seksualitas Di Indonesia. Makalah dipresentasikan pada semiloka hak atas kebebasan pribadi bagi kelompok Lesbian, Gay, Biseksual, Interseksual, Transgender dan Transeksual. Komisi Nasional Hak Asasi Manusia, Kuta,15-16 Agustus 2006.

Philips, Abu Ameenah dan Khan, Zafar. 2003. Islam dan Homoseksual (Jakarta: Pustaka Zahra), Cet.1.

Pranata. Tommy Dwi. 2015. Perilaku dan realitas Sosial Kehidupan gay di Samarinda. eJournal Sosiatri-Sosiologi, Vol. 3, No.3.

Putri, S. K. 2008. Proses Coming Out Pada Gay. Diunduh tanggal 28 Maret 2016 dari: http:/www.gunadarma.ac.id/library/ articles/graduate/psycholog y/2007/Artikel_10502236.pdf

Rangkuti, Ramlan Yusuf. 2012. Homoseksual Dalam Perspektif AlQur'an, Asy-Syir'ah, Jurnal Ilmu Syariah dan Hukum, Vol. 46, 


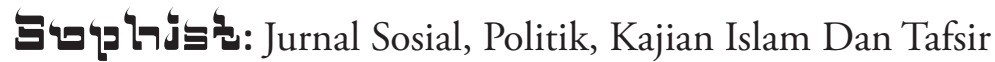

No. 1.

Rosario, Vernon A. 2002. Homosexuality and Science: A Guide to the Debates, (Calivornia: ABC-CLIO).

Sarwono, Sarlito Wirawan. Pengantar Psikologi (Jakarta: Bulan Bintang, 1982).

Sirait, Bigman. LGBT Dalam PerspektifMedis dan Psikologis, diperoleh dari http://www.kompasiana.com/bigmansirait/lgbt-dalamperspektif-medis-dan psikologis $56 \mathrm{efc} 2 \mathrm{cc} 5$ eafbd3f07caf $42 \mathrm{f}$, diakses 17 Agustus 2016.

Spencer, Colin. 2011. Sejarah Homoseksualitas dari Zaman Kuno Hingga Sekarang, diterj oleh Ninik Rochani Sjams, (Bantul: Kreasi Wacana), cet ke-2.

Spitzer, Robert L. 2003. Can Some Gay Men And Lesbians Change Their Sexual Orientation? 200 Participants Reporting A Change From Homosexual To Heterosexual Orientation. Archives of sexual behavior 32.5 .

Stieqlitz, K. A. 2010. Development, Risk, and Resilience of Transgender Youth. Journal of the Association of Nurses in AIDS Care, 21(3), hlm. 192-206.

Suara-Lgbt-Jalan-Lain-Memahami-Hak-Minoritas-1-1, diakses tanggal 5 Juli 2016.

Sugiyono, 2013. Metode Penelitian Pendidikan: Pendekatan Kualitatif, Kuantitatif dan R\&D. (Bandung: Alfabeta).

Suvianita, Khanis. Pandangan Psikolog Tentang kaum LGBT, diperoleh dari http://www.suarakita.org/2015/10/kisahkhanis-suvianita-pandangan-psikolog-tentang-kaum-lgbt/, diakses 13 Agustus 2016.

UU RI No. 1 Tahun 1974, 2007. Tentang Perkawinan dan Kompilasi Hukum Islam. (Bandung: Citra Umbara).

74 Kajian Teoritis Tentang Perilaku Lesbian, Gay, Biseksual,.... 
Walgito, Bimo. 2005. Bimbingan dan Konseling (Studi dan Karir), (Yogyakarta: Andi), hlm. 168

--------,2004. Pengantar Psikologi Umum. (Jakarta: Andi).

-------,2002. Pengantar Psikologi Umum (Yogyakarta: Andi Offset).

Yakan, Fathi. 1989. al-Islam wa al-Jins, terjemahan Syafril Halim, Islam dan Seks (Jakarta: Al-Hidayah).

Yuliana, Tri. 2014. Upaya Australian Marriage Equality dalam Menegakkan HAM Sesuai Resolusi PBB Terkait Masalah Same Sex marriage di Australia. JOM FISIP, Vol. 1, No. 2.

---------,Tt., Eight Major Identical Twin Studies Prove Homosexuality Is Not Genetic, diperoleh dari http://www.redflagnews.com/ headlines/identical-twin-studies-prove-homosexuality-is-notgenetic., diakses tanggal 2 Juli 2016.

2013. Mengerikan!! Angka Penderita AIDS di Indonesia Terus Merangkak naik. Diakses tanggal 7 April 2016 dari : https://indocropcircles.wordpress.com/2013/12/01/angkapenderita-aids-di-indonesia-terus-naik/ 